\title{
Water/Methanol-Insoluble Brown Carbon Can Dominate Aerosol Enhanced Light Absorption in Port Cities
}

Zhe Bai ${ }^{1,2}$, Linyuan Zhang ${ }^{2}$, Yi Cheng ${ }^{1}$, Wei Zhang ${ }^{1}$, Junfang Mao ${ }^{1}$, Ling Li ${ }^{1}$, Hui

Chen $^{1}$, Lina Wang ${ }^{1,2 *}$, Jianmin Chen ${ }^{1,2 *}$

${ }^{1}$ Shanghai Key Laboratory of Atmospheric Particle Pollution and Prevention (LAP3), Department of Environmental Science and Engineering, Fudan University, Shanghai 200433, China.

${ }^{2}$ Shanghai Institute of Pollution Control and Ecological Security, Shanghai 200092, China

${ }^{3}$ State Environmental Protection Key Laboratory of Risk Assessment and Control on Chemical Process, East China University of Science and Technology, Shanghai 200237, China.

Corresponding Author: wanglina@fudan.edu.cn

jmchen@fudan.edu.cn 


\section{Supporting information}

Fig. S1 Map of the sampling site and the ports around the site

Fig. S2 Schematic diagrams of the experimental apparatus and processes. TD: thermal denuder; CAPS 450: light extinction and scattering monitor at $450 \mathrm{~nm}$; CAPS 530: light extinction and scattering monitor at $530 \mathrm{~nm}$; TSI-3563: three-wavelength $(450,550$ and $700 \mathrm{~nm})$ integrated nephelometer

Fig. S3 Conceptual representation of the three different approaches used to estimate the fraction of total absorption contributed by BC (a), BrC (b), and lensing (c) from December 2018 to January 2019

Fig. S4 The absorption of $\mathrm{BrC}$ of the three different approaches and the soluble $\mathrm{BrC}$ at 365 and $450 \mathrm{~nm}$ measured using a UV/Vis spectrometer from December 2018 to January 2019

Fig. S5 Time series from December 2018 to January 2019 of (a) the absorption ångström exponent (AAE) through the TD, (b) the absorption ångström exponent (AAE) not through the TD, (c) the scattering ångström exponent (SAE) for ambient aerosol, and (d) scattering coefficients at 450, 550 and $700 \mathrm{~nm}$

Fig. S6 Mass concentration of humic-like substances (HULIS), biomass burning derived $\mathrm{K}^{+}$, ammonium, and sulfate for ambient aerosol samples

Fig. S7 The MODIS fire counts between Jan2 ${ }^{\text {nd }}$ and Jan $8^{\text {th }} 2019$

Fig. S8 Wind rose plot at Shanghai

Fig. S9 Trend of ion concentration during sampling in Shanghai

Fig. S10 Selected examples of the UV/Vis spectra from the above chromophores and their corresponding elemental composition as inferred from Q-ToFMS

Table S1 Concentrations of four chromophores in aerosol samples (unit: $\mathrm{ng} / \mathrm{m}^{3}$ )

Table S2 Summary of retention times (RT) of major light-absorbing peaks and elemental formulas of the corresponding chromophoric species for Jan $2^{\text {nd }}$ and Jan $8^{\text {th }}$

Table S3 Integration parameter values of each absorption peak at $365 \mathrm{~nm}$ for Jan $2^{\text {nd }}$ and Jan $8^{\text {th }}$ samples

2.2S Analysis of Collected Samples

2.3S Real-time Monitoring of Aerosol Enhanced Light Absorption 


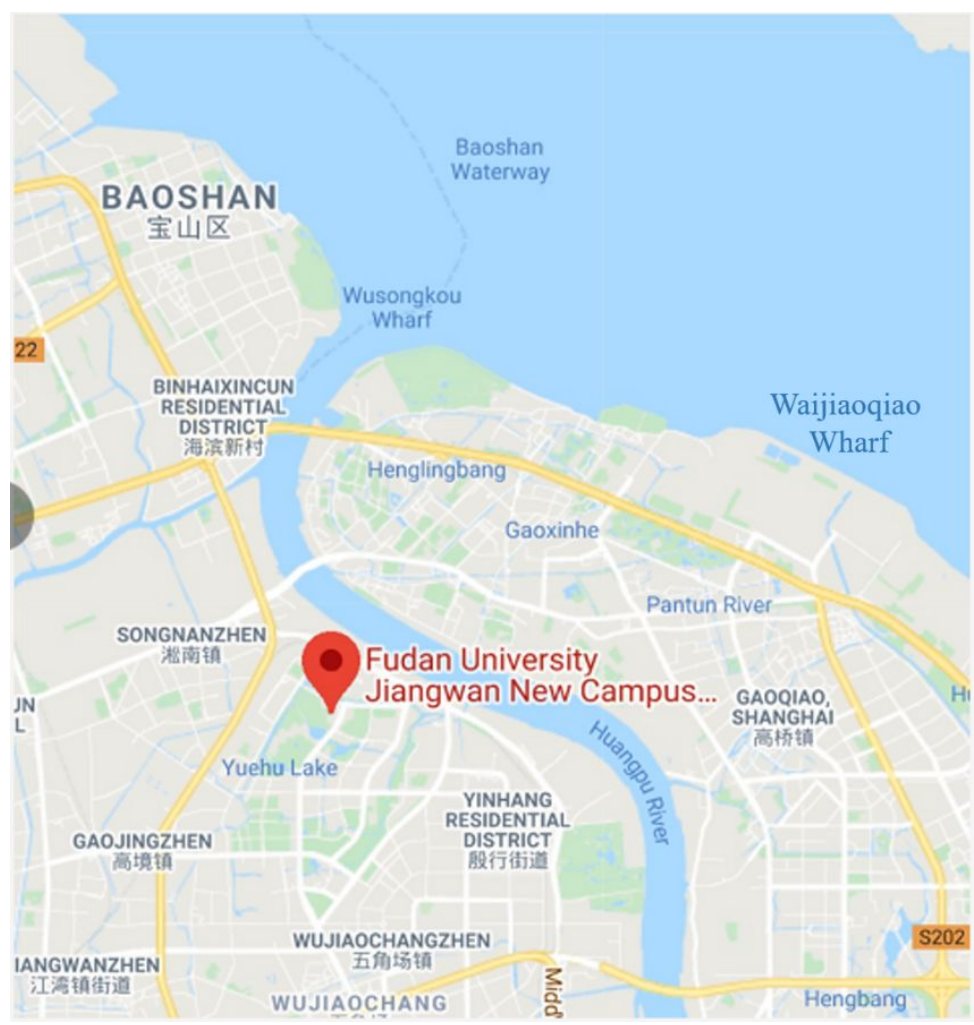

Figure S1. Map of the sampling site and the ports around the site 


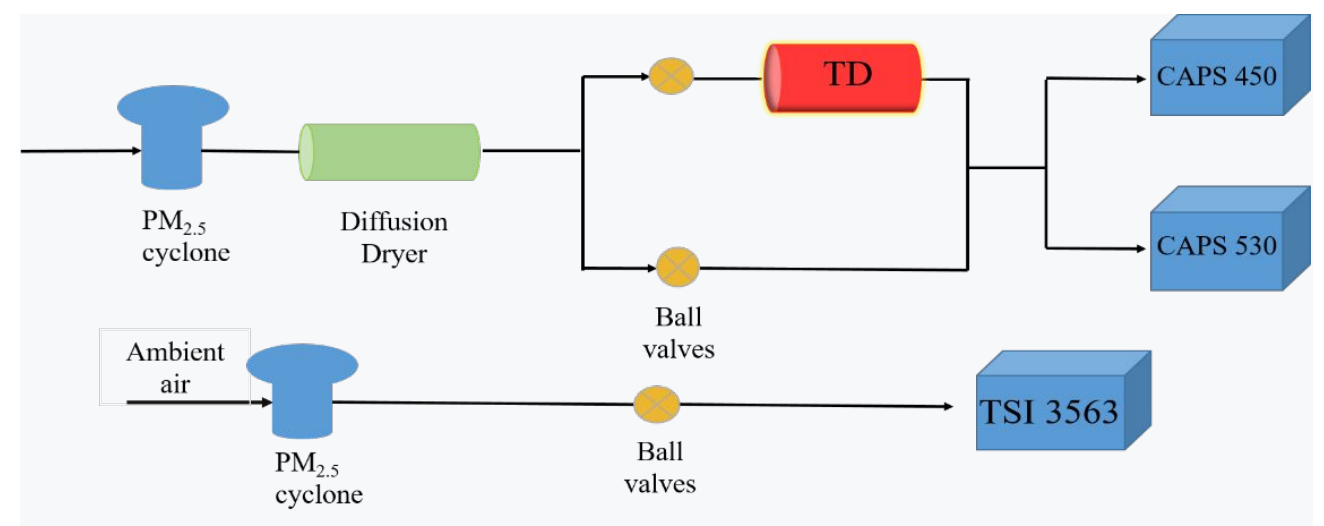

Figure S2. Schematic diagrams of the experimental apparatus and processes (TD: thermal denuder; CAPS 450: light extinction and scattering monitor at $450 \mathrm{~nm}$; CAPS 530: light extinction and scattering monitor at $530 \mathrm{~nm}$; TSI-3563: three-wavelength of 450, 550 and $700 \mathrm{~nm}$ integrated nephelometer) 

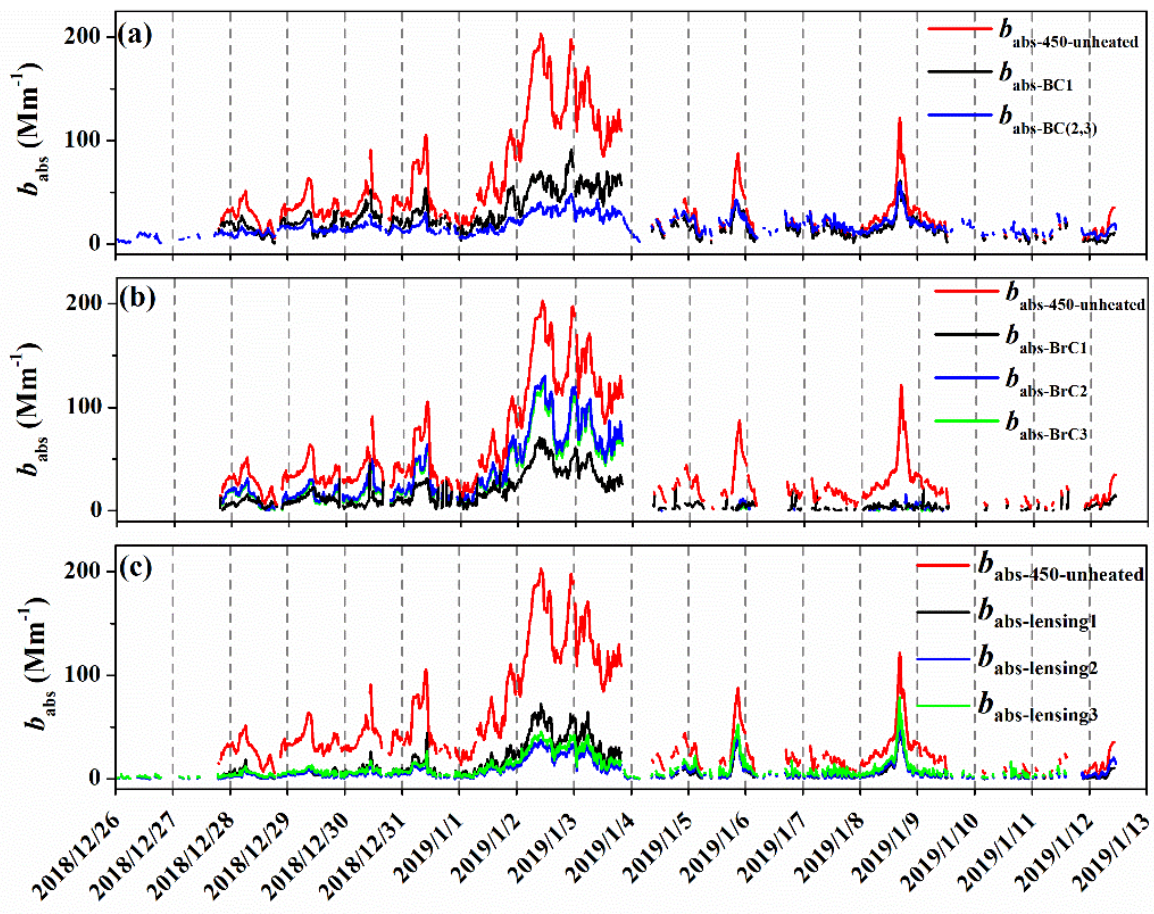

Figure S3. Conceptual representation of the three different approaches used to estimate the fraction of total absorption contributed by BC (a), BrC (b), and lensing (c) from December 2018 to January 2019 


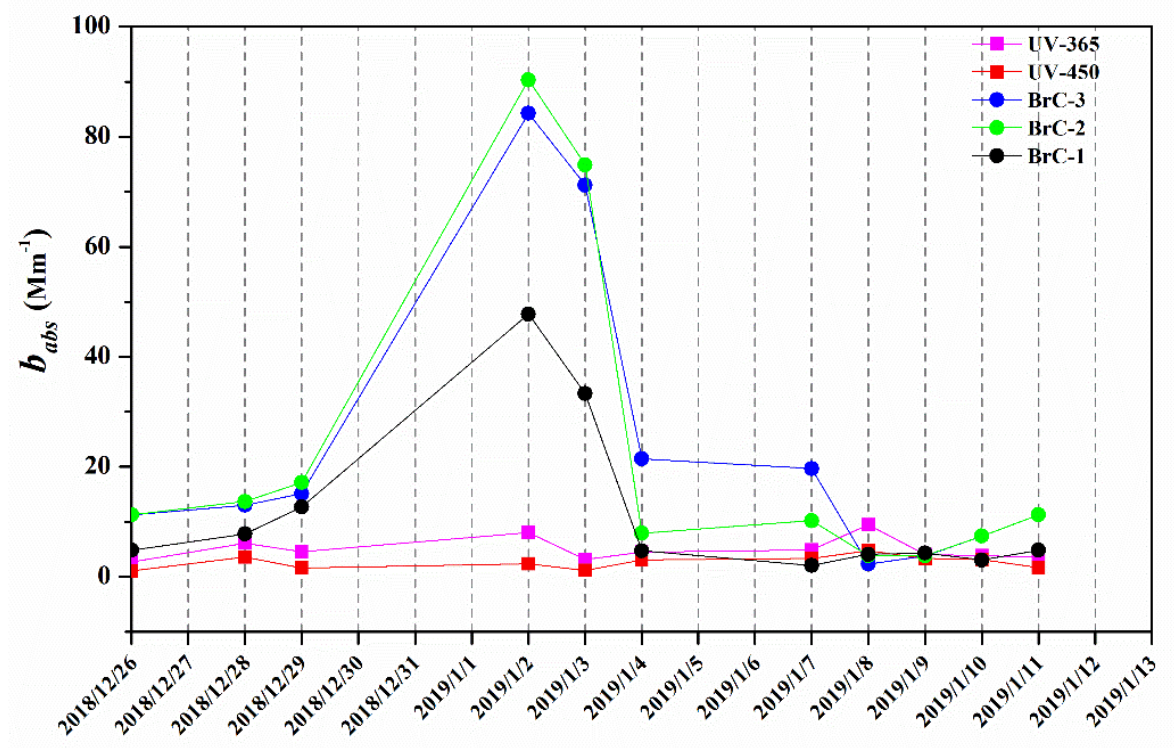

Figure S4. The absorption of $\mathrm{BrC}$ of the three different approaches and the soluble $\mathrm{BrC}$ at 365 and $450 \mathrm{~nm}$ measured using a UV/Vis spectrometer from December 2018 to January 2019 

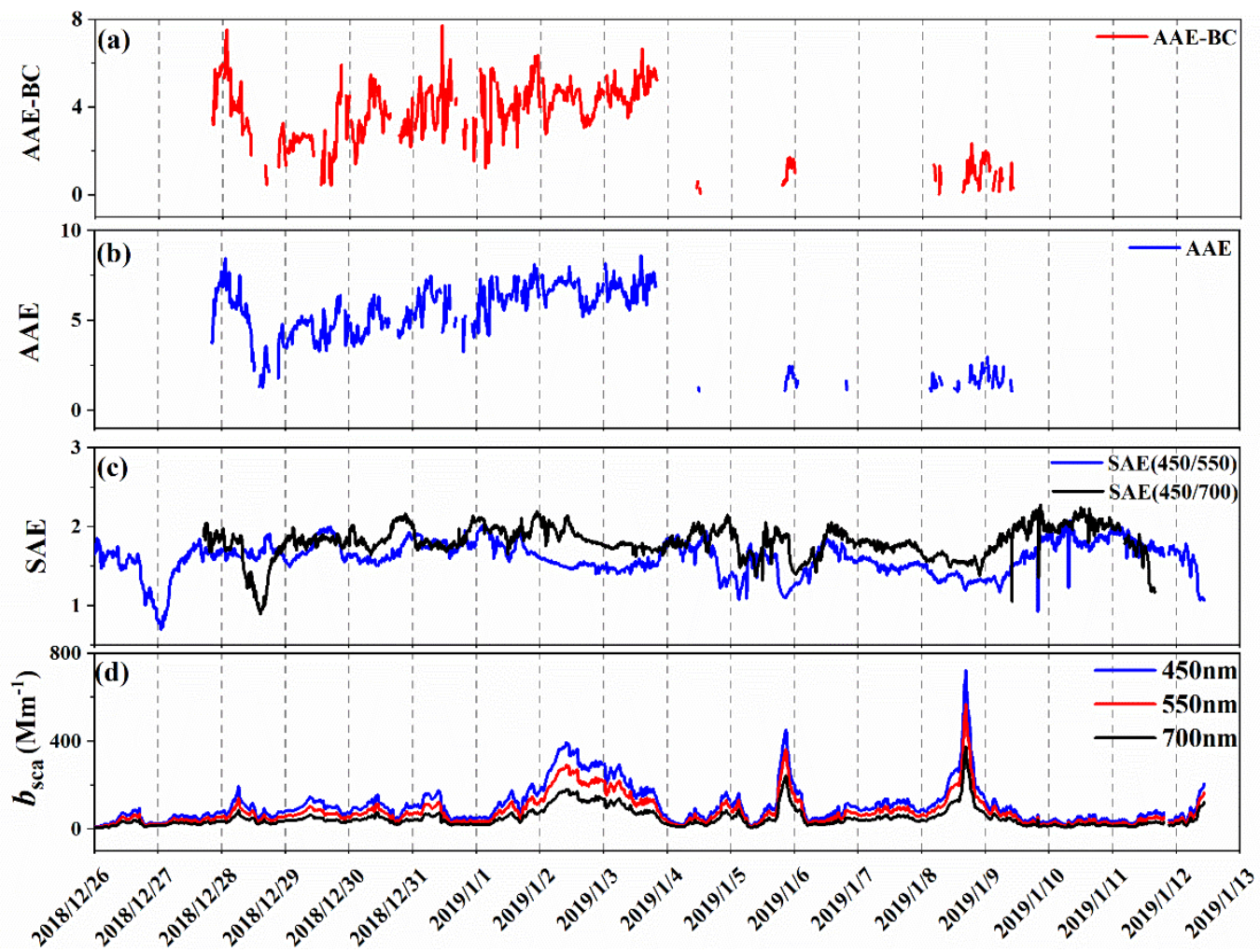

Figure S5. Time series from December 2018 to January 2019 of (a) the absorption ångström exponent (AAE) through the $\mathrm{TD}$, (b) the absorption ångström exponent (AAE) not through the TD, (c) the scattering ångström exponent (SAE) for ambient aerosol, and (d) scattering coefficients at 450, 550 and $700 \mathrm{~nm}$ 

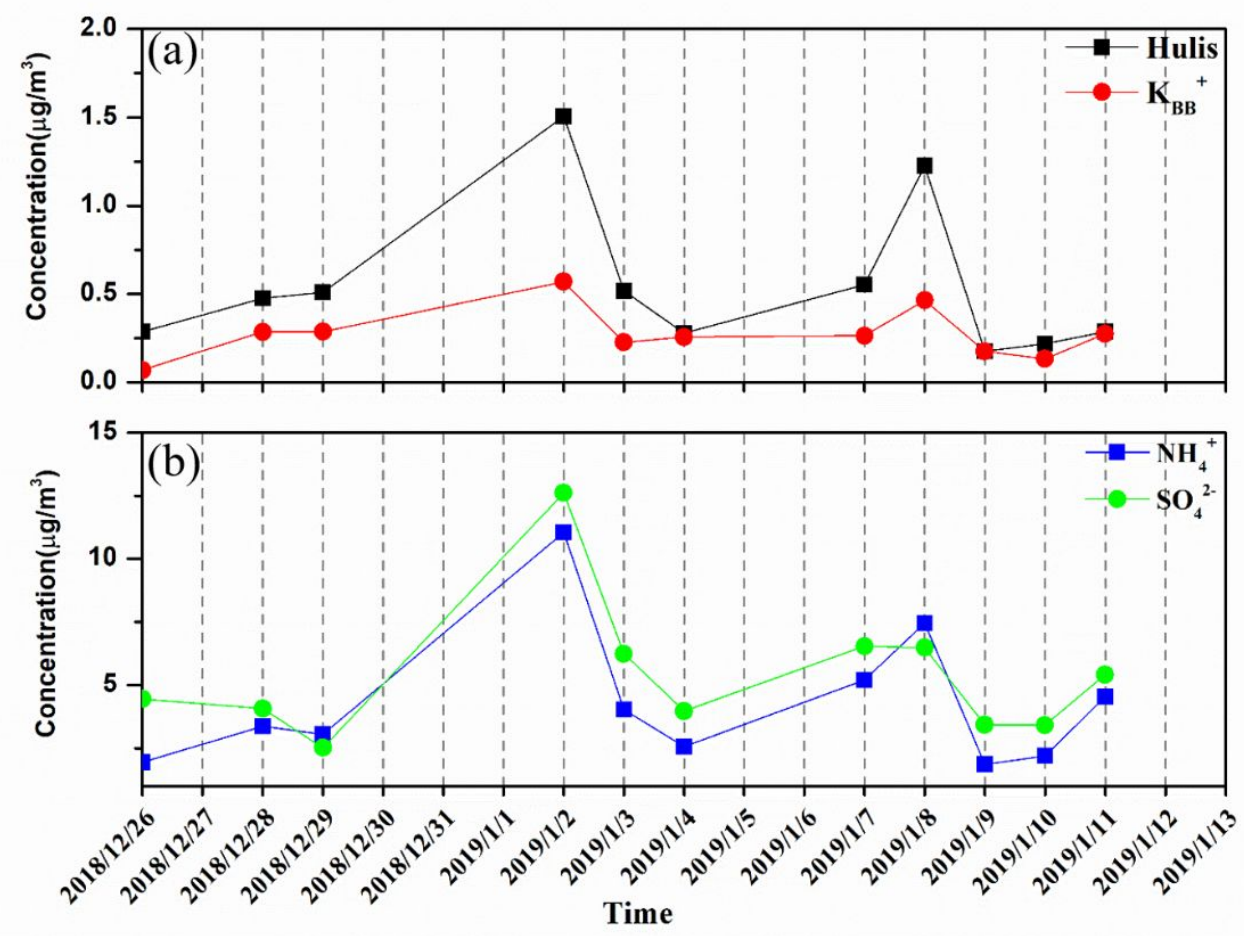

Figure S6. Mass concentration of humic-like substances (HULIS), biomass burning derived $\mathrm{K}^{+}$, ammonium, and sulfate for ambient aerosol samples 

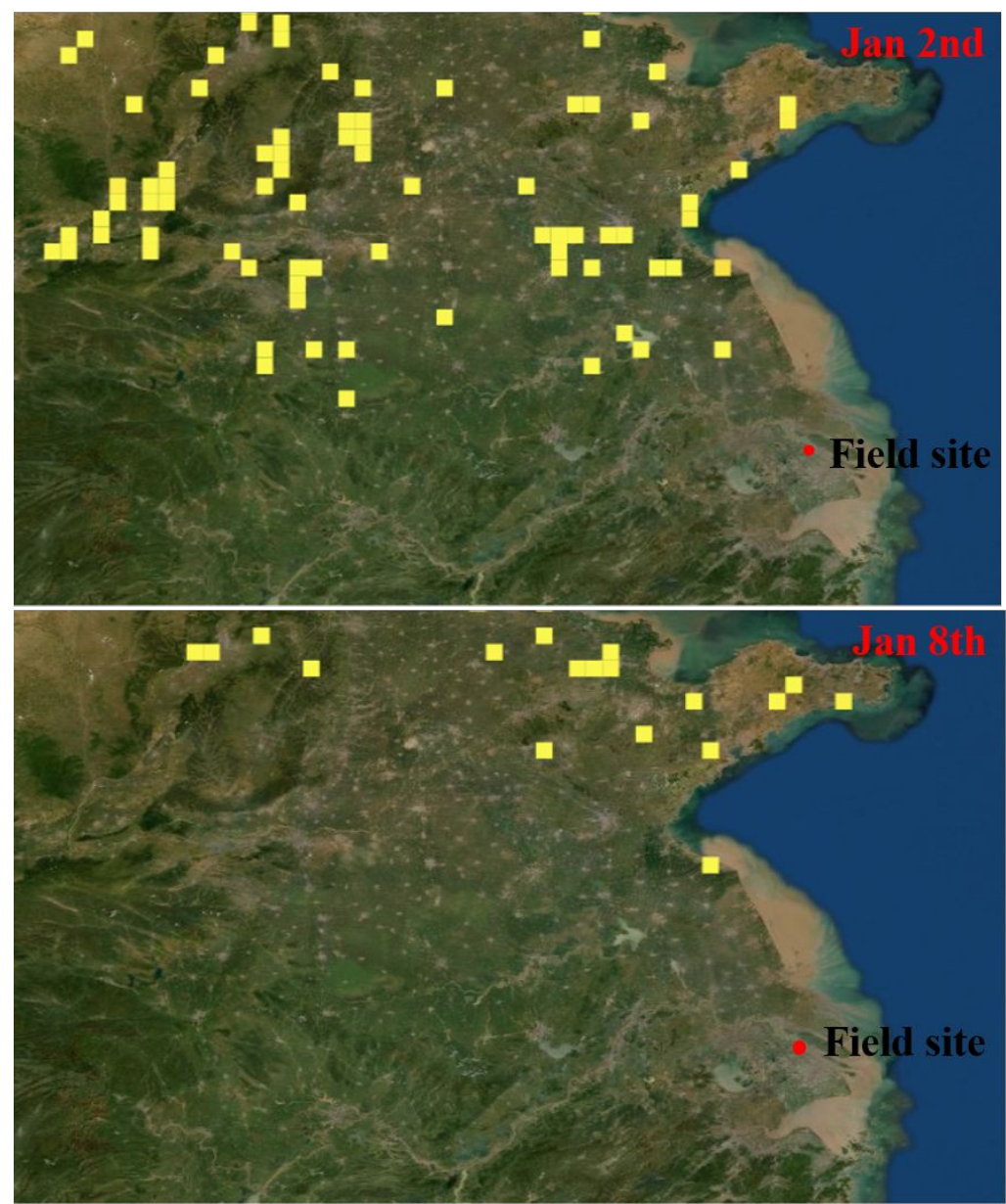

Figure S7. The MODIS fire counts between Jan2 ${ }^{\text {nd }}$ and Jan $8^{\text {th }} 2019$

(https://firms.modaps.eosdis.nasa.gov/map) 

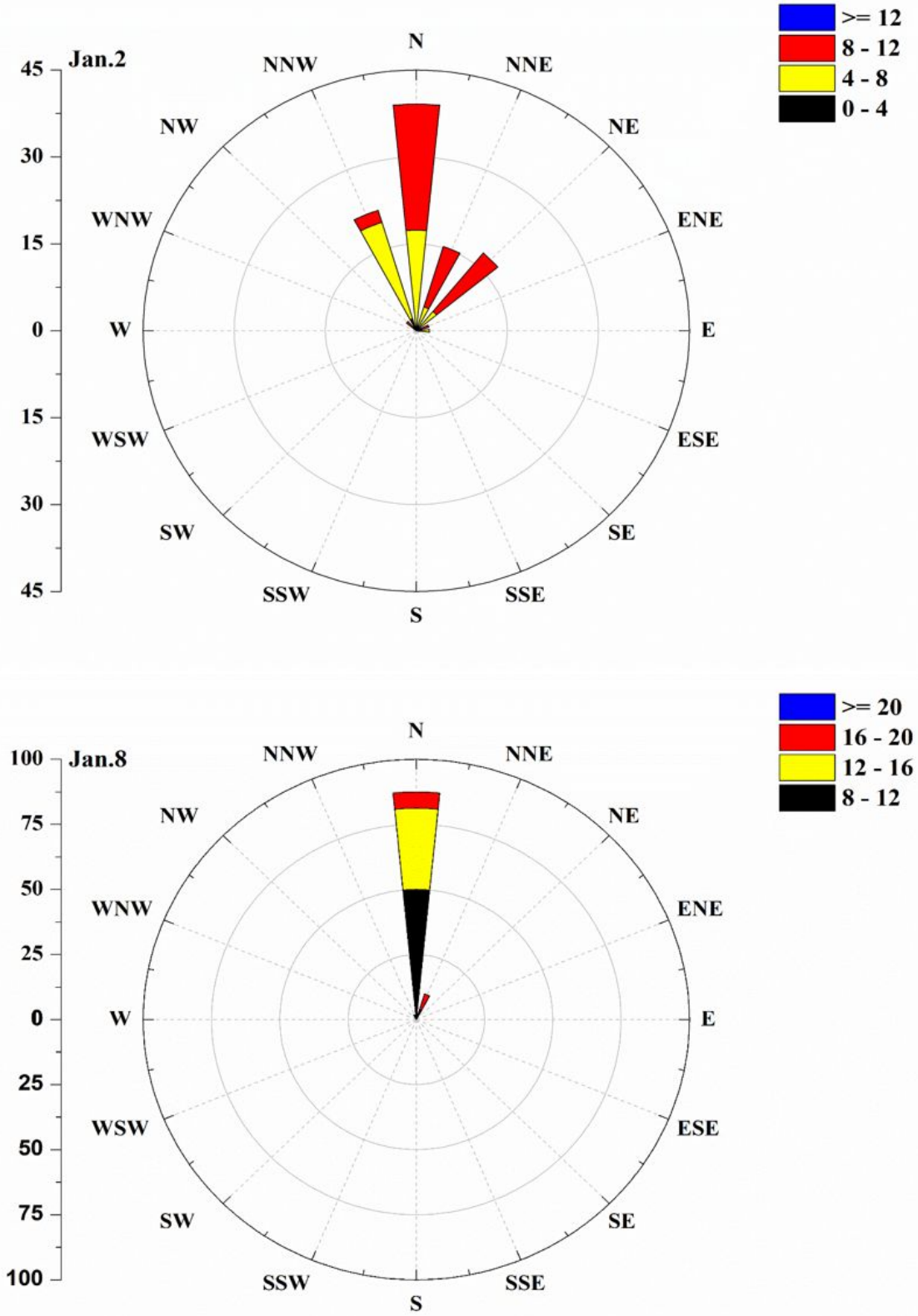

Figure S8.Wind rose plot at Shanghai 


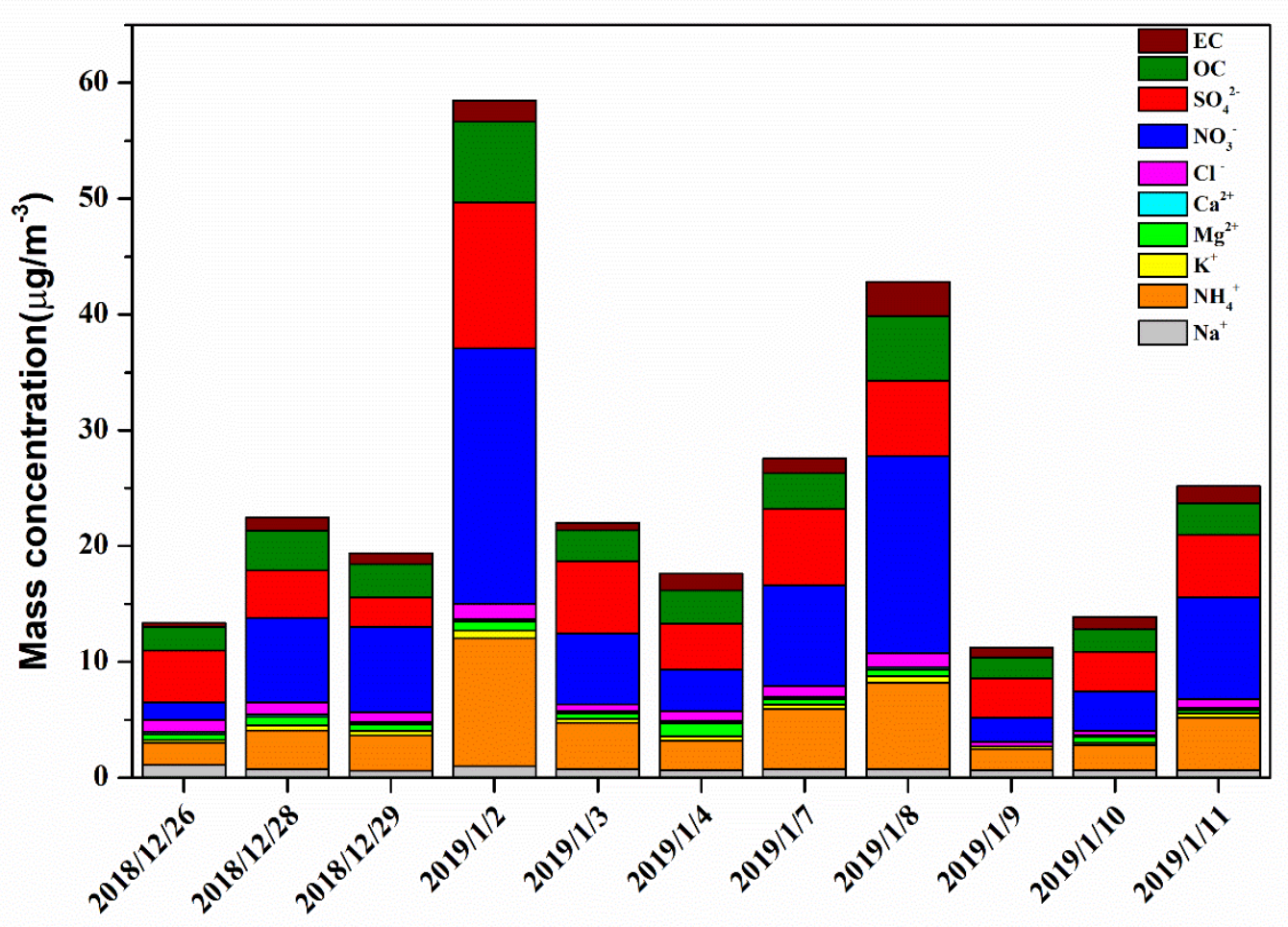

Figure S9. Trend of ion concentrations during sampling in Shanghai 

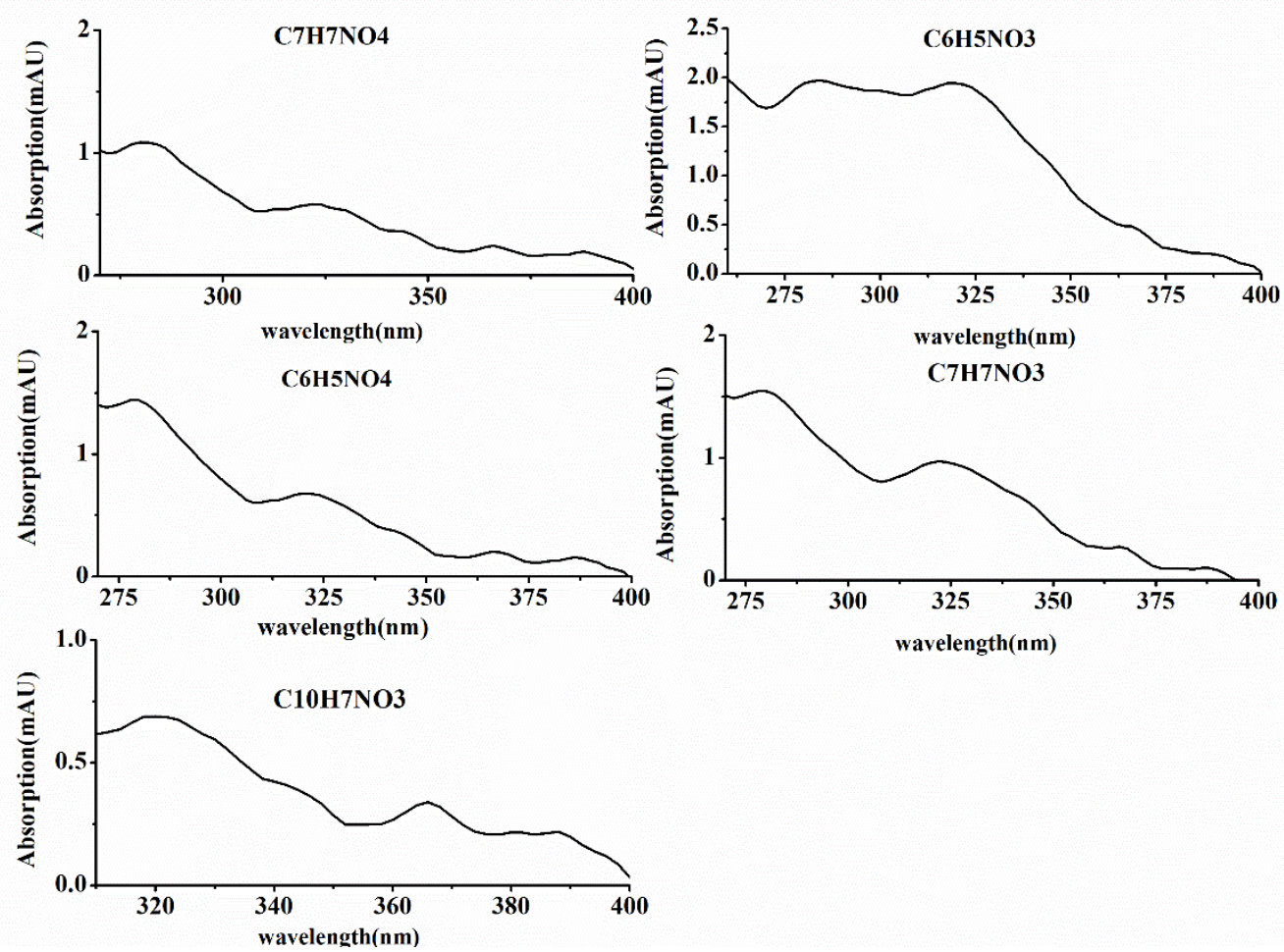

wavelength(nm)

Figure S10. Selected examples of the UV/Vis spectra from the above chromophores and their corresponding elemental composition as inferred from Q-ToF-MS 
Table S1 Concentrations of four chromophores in aerosol samples (unit: $\mathrm{ng} / \mathrm{m}^{3}$ )

\begin{tabular}{cccccc}
\hline Sample & 4-nitrophenol & 4-niteocatechol & $\begin{array}{c}\text { 3-methyl-4- } \\
\text { nitrophenol }\end{array}$ & $\begin{array}{c}\text { 2-methyl-4- } \\
\text { nitrophenol }\end{array}$ & $\begin{array}{c}\text { 2-nitro-1- } \\
\text { naphthol }\end{array}$ \\
\hline 2 Jan & 0.837 & 182.252 & & & 2.922 \\
3 Jan & & 56.940 & & - & 0.675 \\
7 Jan & 0.247 & 42.334 & - & 0.779 \\
8 Jan & 0.738 & 106.627 & - & 1.616 \\
9 Jan & & 8.645 & - & 0.225 \\
\hline
\end{tabular}

Table S2 Summary of retention times (RT) of major light-absorbing peaks and elemental formulas of the corresponding chromophoric species for Jan $2^{\text {nd }}$ and Jan $8^{\text {th }}$

\begin{tabular}{|c|c|c|c|c|c|}
\hline Jan2 & ESI- & $\mathrm{RT} / \mathrm{min}$ & $\mathrm{m} / \mathrm{z}$ & Formula & Score \\
\hline & 1 & 7.530 & 168.0303 & $\mathrm{C}_{7} \mathrm{H}_{7} \mathrm{NO}_{4}$ & 83.21 \\
\hline & 2 & 9.386 & 138.0199 & $\mathrm{C}_{6} \mathrm{H}_{5} \mathrm{NO}_{3}$ & 99.71 \\
\hline & 3 & 9.753 & 154.0146 & $\mathrm{C}_{6} \mathrm{H}_{5} \mathrm{NO}_{4}$ & 97.24 \\
\hline & 4 & 9.999 & 177.0558 & $\mathrm{C}_{10} \mathrm{H}_{10} \mathrm{O}_{3}$ & 99.1 \\
\hline & 5 & 10.608 & 187.0980 & $\mathrm{C}_{9} \mathrm{H}_{16} \mathrm{O}_{4}$ & 99.04 \\
\hline & 6 & 10.852 & 164.0353 & $\mathrm{C}_{8} \mathrm{H}_{7} \mathrm{NO}_{3}$ & 99.41 \\
\hline & 7 & 11.195 & 294.0657 & $\mathrm{C}_{10} \mathrm{H}_{17} \mathrm{NO}_{7} \mathrm{~S}$ & 94.02 \\
\hline & 8 & 12.014 & 161.0357 & $\mathrm{C}_{8} \mathrm{H}_{6} \mathrm{~N}_{2} \mathrm{O}_{2}$ & 99.46 \\
\hline & 9 & 12.176 & 152.0354 & $\mathrm{C}_{7} \mathrm{H}_{7} \mathrm{NO}_{3}$ & 99.75 \\
\hline & 10 & 12.899 & 294.0655 & $\mathrm{C}_{10} \mathrm{H}_{17} \mathrm{NO}_{7} \mathrm{~S}$ & 96.74 \\
\hline & 11 & 14.38 & 217.1450 & $\mathrm{C}_{11} \mathrm{H}_{22} \mathrm{O}_{4}$ & 98.59 \\
\hline & 12 & 14.485 & 313.0722 & $\mathrm{C}_{10} \mathrm{H}_{7} \mathrm{NO}_{3}$ & 99.82 \\
\hline & 13 & 15.693 & 228.0303 & $\mathrm{C}_{12} \mathrm{H}_{7} \mathrm{NO}_{4}$ & 99.7 \\
\hline \multirow{2}{*}{\multicolumn{2}{|c|}{14}} & 16.246 & 177.0920 & $\mathrm{C}_{11} \mathrm{H}_{14} \mathrm{O}_{2}$ & 98.21 \\
\hline & & & & $\mathrm{C}_{9} \mathrm{H}_{12} \mathrm{~N}_{3} \mathrm{O}$ & 91.47 \\
\hline & 15 & 17.223 & 242.0459 & $\mathrm{C}_{13} \mathrm{H}_{9} \mathrm{NO}_{4}$ & 99.17 \\
\hline & 16 & 18.61 & 297.1531 & $\mathrm{C}_{16} \mathrm{H}_{26} \mathrm{O}_{3} \mathrm{~S}$ & 97.94 \\
\hline & 17 & 19.341 & 311.1687 & $\mathrm{C}_{17} \mathrm{H}_{28} \mathrm{O}_{3} \mathrm{~S}$ & 97.14 \\
\hline & 18 & 19.877 & 325.1846 & $\mathrm{C}_{18} \mathrm{H}_{30} \mathrm{O}_{3} \mathrm{~S}$ & 96.22 \\
\hline & 19 & 20.565 & 339.2007 & $\mathrm{C}_{19} \mathrm{H}_{32} \mathrm{O}_{3} \mathrm{~S}$ & 97.38 \\
\hline \multirow{2}{*}{\multicolumn{2}{|c|}{20}} & 21.204 & 227.2017 & $\mathrm{C}_{14} \mathrm{H}_{28} \mathrm{O}_{2}$ & 99.95 \\
\hline & & & & $\mathrm{C}_{12} \mathrm{H}_{26} \mathrm{~N}_{3} \mathrm{O}$ & 90.25 \\
\hline & 21 & 21.428 & 375.2757 & $\mathrm{C}_{20} \mathrm{H}_{40} \mathrm{O}_{6}$ & 98.37 \\
\hline & 22 & 22.213 & 255.2333 & $\mathrm{C}_{16} \mathrm{H}_{32} \mathrm{O}_{2}$ & 99.41 \\
\hline & & & & $\mathrm{C}_{15} \mathrm{H}_{34} \mathrm{~N}_{3}$ & 98.13 \\
\hline & & & & $\mathrm{C}_{17} \mathrm{H}_{36} \mathrm{O}$ & 91.26 \\
\hline \multirow[t]{4}{*}{$\begin{array}{c}\text { Jan8 } \\
\text { th }\end{array}$} & ESI- & $\mathrm{RT} / \mathrm{min}$ & $\mathrm{m} / \mathrm{z}$ & Formula & Score \\
\hline & 1 & 9.358 & 138.0200 & $\mathrm{C}_{6} \mathrm{H}_{5} \mathrm{NO}_{3}$ & 98.49 \\
\hline & 2 & 9.950 & 154.0146 & $\mathrm{C}_{6} \mathrm{H}_{5} \mathrm{NO}_{4}$ & 93.64 \\
\hline & 3 & 10.828 & 164.0353 & $\mathrm{C}_{8} \mathrm{H}_{7} \mathrm{NO}_{3}$ & 99.64 \\
\hline
\end{tabular}




\begin{tabular}{|c|c|c|c|c|}
\hline 4 & 11.997 & 161.0357 & $\mathrm{C}_{8} \mathrm{H}_{6} \mathrm{~N}_{2} \mathrm{O}_{2}$ & 98.97 \\
\hline 5 & 12.160 & 152.0358 & $\mathrm{C}_{7} \mathrm{H}_{7} \mathrm{NO}_{3}$ & 99.53 \\
\hline 6 & 13.442 & 166.0511 & $\mathrm{C}_{8} \mathrm{H}_{9} \mathrm{NO}_{3}$ & 98.90 \\
\hline 7 & 14.365 & 241.1441 & $\mathrm{C}_{13} \mathrm{H}_{22} \mathrm{O}_{4}$ & 95.63 \\
\hline 8 & 14.440 & 188.0355 & $\mathrm{C}_{10} \mathrm{H}_{7} \mathrm{NO}_{3}$ & 99.48 \\
\hline 9 & 15.908 & 293.1760 & $\mathrm{C}_{17} \mathrm{H}_{26} \mathrm{O}_{4}$ & 98.45 \\
\hline 10 & 16.108 & 143.1078 & $\mathrm{C}_{8} \mathrm{H}_{16} \mathrm{O}_{25}$ & 98.64 \\
\hline 11 & 16.660 & 351.1849 & $\mathrm{C}_{10} \mathrm{H}_{13} \mathrm{NO}_{3}$ & 99.77 \\
\hline 12 & 17.191 & 242.0461 & $\mathrm{C}_{13} \mathrm{H}_{9} \mathrm{NO}_{4}$ & 98.81 \\
\hline 13 & 19.298 & 271.2276 & $\mathrm{C}_{16} \mathrm{H}_{32} \mathrm{O}_{3}$ & 99.17 \\
\hline 14 & 19.499 & 325.1845 & $\mathrm{C}_{18} \mathrm{H}_{30} \mathrm{O}_{3} \mathrm{~S}$ & 96.30 \\
\hline 15 & 19.603 & 415.2312 & $\mathrm{C}_{18} \mathrm{H}_{30} \mathrm{O}_{3} \mathrm{~S}$ & 96.92 \\
\hline 16 & 19.826 & 419.3000 & $\mathrm{C}_{22} \mathrm{H}_{44} \mathrm{O}_{7}$ & 92.77 \\
\hline 17 & 20.275 & 299.2595 & $\mathrm{C}_{18} \mathrm{H}_{36} \mathrm{O}_{3}$ & 98.94 \\
\hline 18 & 20.508 & 417.3406 & $\mathrm{C}_{30} \mathrm{H}_{44} \mathrm{~N}$ & 95.98 \\
\hline 19 & 21.037 & 417.3406 & $\mathrm{C}_{30} \mathrm{H}_{44} \mathrm{~N}$ & 95.98 \\
\hline 20 & 21.478 & 375.2760 & $\mathrm{C}_{20} \mathrm{H}_{40} \mathrm{O}_{6}$ & 93.23 \\
\hline 21 & 21.649 & 279.2331 & $\mathrm{C}_{18} \mathrm{H}_{32} \mathrm{O}_{2}$ & 99.16 \\
\hline 22 & 22.399 & 403.3069 & $\mathrm{C}_{22} \mathrm{H}_{44} \mathrm{O}_{6}$ & 97.83 \\
\hline 23 & 22.577 & 391.2885 & $\mathrm{C}_{27} \mathrm{H}_{38} \mathrm{NO}$ & 96.72 \\
\hline 24 & 22.973 & 417.3407 & $\mathrm{C}_{24} \mathrm{H}_{50} \mathrm{O}_{3} \mathrm{~S}$ & 96.31 \\
\hline 25 & 23.165 & 283.2647 & $\mathrm{C}_{18} \mathrm{H}_{36} \mathrm{O}_{2}$ & 99.38 \\
\hline 26 & 24.241 & 297.2798 & $\mathrm{C}_{19} \mathrm{H}_{38} \mathrm{O}_{2}$ & 99.83 \\
\hline 27 & 24.973 & 457.3719 & $\mathrm{C}_{33} \mathrm{H}_{48} \mathrm{~N}$ & 97.04 \\
\hline 28 & 25.713 & 621.4371 & $\mathrm{C}_{36} \mathrm{H}_{32} \mathrm{O}_{8}$ & 98.84 \\
\hline 29 & 26.065 & 929.7853 & $\mathrm{C}_{55} \mathrm{H}_{11} \mathrm{O}_{8} \mathrm{~S}$ & 94.53 \\
\hline
\end{tabular}

Table S3 Integration parameter values of each absorption peak at $365 \mathrm{~nm}$ for Jan $2^{\text {nd }}$ and Jan $8^{\text {th }}$

\begin{tabular}{ccccccc}
\hline \multicolumn{7}{c}{ Samples } \\
\hline Pan ${ }^{\text {nd }}$ & RT & Area & Area $\%$ & Height & Height $\%$ & Width \\
\hline 1 & & & & & & \\
2 & 0.934 & 0.30 & $2 \%$ & 0.13 & $3 \%$ & 0.077 \\
3 & 0.994 & 0.24 & $2 \%$ & 0.2 & $4 \%$ & 0.03 \\
4 & 1.475 & 0.76 & $5 \%$ & 0.32 & $7 \%$ & 0.093 \\
5 & 1.689 & 0.51 & $3 \%$ & 0.07 & $1 \%$ & 0.207 \\
6 & 7.52 & 0.13 & $1 \%$ & 0.03 & $1 \%$ & 0.141 \\
7 & 9.376 & 1.2 & $8 \%$ & 0.33 & $7 \%$ & 0.139 \\
8 & 9.989 & 0.14 & $1 \%$ & 0.04 & $1 \%$ & 0.109 \\
9 & 10.598 & 0.52 & $3 \%$ & 0.13 & $3 \%$ & 0.155 \\
10 & 10.842 & 3.22 & $22 \%$ & 1 & $21 \%$ & 0.147 \\
11 & 11.185 & 0.22 & $1 \%$ & 0.06 & $1 \%$ & 0.125 \\
12 & 12.004 & 0.67 & $4 \%$ & 0.2 & $4 \%$ & 0.132 \\
13 & 12.166 & 0.63 & $4 \%$ & 0.14 & $3 \%$ & 0.149 \\
& 12.889 & 0.2 & $1 \%$ & 0.06 & $1 \%$ & 0.109
\end{tabular}




\begin{tabular}{|c|c|c|c|c|c|c|}
\hline 14 & 14.37 & 0.8 & $5 \%$ & 0.27 & $6 \%$ & 0.112 \\
\hline 15 & 14.475 & 0.34 & $2 \%$ & 0.12 & $2 \%$ & 0.093 \\
\hline 16 & 15.683 & 0.13 & $1 \%$ & 0.04 & $1 \%$ & 0.111 \\
\hline 17 & 16.123 & 0.27 & $2 \%$ & 0.1 & $2 \%$ & 0.085 \\
\hline 18 & 16.236 & 0.12 & $1 \%$ & 0.05 & $1 \%$ & 0.084 \\
\hline 19 & 17.213 & 0.32 & $2 \%$ & 0.1 & $2 \%$ & 0.106 \\
\hline 20 & 18.098 & 0.19 & $1 \%$ & 0.09 & $2 \%$ & 0.071 \\
\hline 21 & 18.6 & 0.14 & $1 \%$ & 0.06 & $1 \%$ & 0.07 \\
\hline 22 & 19.331 & 0.24 & $2 \%$ & 0.09 & $2 \%$ & 0.097 \\
\hline 23 & 19.634 & 0.63 & $4 \%$ & 0.2 & $4 \%$ & 0.176 \\
\hline 24 & 19.867 & 0.27 & $2 \%$ & 0.06 & $1 \%$ & 0.148 \\
\hline 25 & 20.555 & 0.24 & $2 \%$ & 0.07 & $1 \%$ & 0.116 \\
\hline 26 & 21.08 & 0.16 & $1 \%$ & 0.08 & $2 \%$ & \\
\hline 27 & 21.194 & 0.71 & $5 \%$ & 0.22 & $5 \%$ & 0.129 \\
\hline 28 & 21.418 & 0.58 & $4 \%$ & 0.21 & $4 \%$ & 0.093 \\
\hline 29 & 22.101 & 0.35 & $2 \%$ & 0.14 & $3 \%$ & 0.087 \\
\hline 30 & 22.203 & 0.59 & $4 \%$ & 0.18 & $4 \%$ & 0.106 \\
\hline 31 & 23.229 & 0.14 & $1 \%$ & 0.03 & $1 \%$ & 0.186 \\
\hline $\operatorname{Jan} 8^{\text {th }}$ & RT & Area & Area $\%$ & Height & Height $\%$ & Width \\
\hline \multicolumn{7}{|l|}{ Peak } \\
\hline 1 & 0.927 & 0.34 & $4 \%$ & 0.17 & $8 \%$ & 0.056 \\
\hline 2 & 6.038 & 0.11 & $1 \%$ & 0.02 & $1 \%$ & 0.168 \\
\hline 3 & 9.348 & 0.66 & $9 \%$ & 0.19 & $8 \%$ & 0.127 \\
\hline 4 & 10.818 & 0.36 & $5 \%$ & 0.12 & $5 \%$ & 0.107 \\
\hline 5 & 11.987 & 0.11 & $1 \%$ & 0.04 & $2 \%$ & 0.088 \\
\hline 6 & 12.15 & 0.45 & $6 \%$ & 0.09 & $4 \%$ & 0.149 \\
\hline 7 & 13.432 & 0.08 & $1 \%$ & 0.02 & $1 \%$ & 0.132 \\
\hline 8 & 14.355 & 0.31 & $4 \%$ & 0.1 & $4 \%$ & 0.088 \\
\hline 9 & 14.43 & 0.24 & $3 \%$ & 0.07 & $3 \%$ & 0.11 \\
\hline 10 & 15.898 & 0.25 & $3 \%$ & 0.08 & $4 \%$ & 0.141 \\
\hline 11 & 16.098 & 0.09 & $1 \%$ & 0.04 & $2 \%$ & 0.066 \\
\hline 12 & 16.65 & 0.11 & $1 \%$ & 0.03 & $1 \%$ & 0.119 \\
\hline 13 & 17.181 & 0.28 & $4 \%$ & 0.09 & $4 \%$ & 0.108 \\
\hline 14 & 18.068 & 0.14 & $2 \%$ & 0.06 & $3 \%$ & 0.087 \\
\hline 15 & 19.288 & 0.11 & $1 \%$ & 0.04 & $2 \%$ & 0.087 \\
\hline 16 & 19.489 & 0.13 & $2 \%$ & 0.02 & $1 \%$ & 0.121 \\
\hline 17 & 19.593 & 0.22 & $3 \%$ & 0.08 & $4 \%$ & 0.091 \\
\hline 18 & 19.816 & 0.15 & $2 \%$ & 0.04 & $2 \%$ & 0.146 \\
\hline 19 & 20.265 & 0.16 & $2 \%$ & 0.07 & $3 \%$ & 0.067 \\
\hline 20 & 20.498 & 0.11 & $1 \%$ & 0.04 & $2 \%$ & 0.088 \\
\hline 21 & 21.027 & 0.14 & $2 \%$ & 0.05 & $2 \%$ & 0.113 \\
\hline 22 & 21.139 & 0.41 & $5 \%$ & 0.12 & $5 \%$ & 0.137 \\
\hline 23 & 21.363 & 0.24 & $3 \%$ & 0.1 & $4 \%$ & 0.07 \\
\hline 24 & 21.468 & 0.16 & $2 \%$ & 0.04 & $2 \%$ & 0.115 \\
\hline
\end{tabular}




\begin{tabular}{ccccccc}
25 & 21.639 & 0.27 & $4 \%$ & 0.04 & $2 \%$ & 0.218 \\
26 & 22.042 & 0.24 & $3 \%$ & 0.09 & $4 \%$ & 0.091 \\
27 & 22.138 & 0.32 & $4 \%$ & 0.11 & $5 \%$ & 0.088 \\
28 & 22.389 & 0.2 & $3 \%$ & 0.04 & $2 \%$ & 0.166 \\
29 & 22.567 & 0.22 & $3 \%$ & 0.06 & $3 \%$ & 0.149 \\
30 & 22.963 & 0.28 & $4 \%$ & 0.03 & $1 \%$ & 0.238 \\
31 & 23.155 & 0.2 & $3 \%$ & 0.04 & $2 \%$ & 0.178 \\
32 & 24.231 & 0.16 & $2 \%$ & 0.03 & $1 \%$ & 0.167 \\
33 & 24.963 & 0.11 & $1 \%$ & 0.02 & $1 \%$ & 0.096 \\
34 & 25.702 & 0.09 & $1 \%$ & 0.02 & $1 \%$ & 0.131 \\
35 & 26.055 & 0.13 & $2 \%$ & 0.04 & $2 \%$ & 0.1 \\
\hline
\end{tabular}




\subsection{S Analysis of Collected Samples}

Because of rainy and foggy weather, some samples were wet. Considering the wet samples may affect the results, so only 11 filter samples were used in the study. A diameter of $47 \mathrm{~mm}$ punch of each filter sample was extracted ultrasonically with methanol $(30 \mathrm{~mL})$ for $30 \mathrm{~min}$, followed by filtration and analysis with water-soluble inorganic ions $\mathrm{Na}^{+}, \mathrm{NH}_{4}^{+}, \mathrm{K}^{+}, \mathrm{Mg}^{2+}, \mathrm{Ca}^{2+}, \mathrm{Cl}^{-}, \mathrm{NO}^{3-}$, and $\mathrm{SO}_{4}{ }^{2-}$ ) using ion chromatography. $\mathrm{K}^{+}$could be used to indicate the influence of biomass burning on ambient aerosols. ${ }^{1}$ The portion that is not attributed to soil dust or sea salt is considered to be contributed by biomass burning $\left(\mathrm{K}_{\mathrm{BB}}^{+}\right)$, which better represents the intensity of biomass burning than total $\mathrm{K}^{+}$. The contribution of soil was calculated by multiplying $\left[\mathrm{Ca}^{2+}\right]$ by the K-to-Ca ratio (0.71). ${ }^{1,2}$ A 47 mm-diameter punch of each filter sample was extracted with $30 \mathrm{ml}$ ultrapure water in an ultrasonic bath for $40 \mathrm{~min}$ and then filtered with a $0.22 \mu \mathrm{m}$. The extract was acidified to $\mathrm{pH}=$ 2 using $\mathrm{HCl}$ and then loaded on a solid-phase extraction (SPE) cartridge (Oasis HLB, 300 um, 60 $\mathrm{mg} /$ cartridge, Waters, USA). The organic compounds retained on the cartridge were eluted using 2 $\mathrm{mL}$ of methanol containing $2 \%$ aqueous ammonia $(\mathrm{w} / \mathrm{w})$. The eluate was immediately evaporated to dryness under a gentle $\mathrm{N}_{2}$ stream and redissolved in $30 \mathrm{~mL}$ water for analysis. The organic matter obtained by this procedure is usually termed as HULIS.

The $47 \mathrm{~mm}$-diameter punch of each filter (2 Jan, 3 Jan, 7 Jan, 8 Jan, 9 Jan) was extracted with $30 \mathrm{ml}$ methanol in an ultrasonic bath for $30 \mathrm{~min}$. The extracts were filtered using syringe filters with a $0.22 \mu \mathrm{m}$ polytetrafluoroethylene (PTFE) membrane to remove insoluble fractions. After filtration and concentration, the final volume was approximately $1 \mathrm{ml}$ (2 Jan and $8 \mathrm{Jan}$ ) and $250 \mu \mathrm{L}$ (3 Jan, 7 Jan, and 9 Jan) prior to HPLC/DAD-Q-ToF-MS analysis. The identification and quantification of target $\mathrm{N}$-containing aromatic compounds and S-containing aromatic compounds were conducted with HPLC (1290 series, Agilent Technologies) equipped with a C18 column (SB-C18, $3.0 \times 100 \mathrm{~mm}, 1.8 \mu \mathrm{m}$ particle size, Agilent Technologies) coupled to a UV/Vis DAD (G1315C, Agilent Technologies) followed by a Q-ToFMS (Agilent 6546), which was equipped with a soft ionization source (ESI) in full scan mode (50-1200 Da) and operated in both negative and positive ion modes. The flow rate of the column was set at $0.4 \mathrm{mLmin}^{-1}$ with an injection volume of $2 \mu \mathrm{L}$, and the gradient separation was conducted with $0.1 \%$ acetic acid $(\mathrm{v} / \mathrm{v})$ in water (eluent $\mathrm{A}$ ) and methanol (eluent B). The concentration of eluent B was $5 \%$ for the first $0.5 \mathrm{~min}$, held at $95 \%$ from 0.5 to $27 \mathrm{~min}$, and then decreased back to $5 \%$ from 27 to $27.1 \mathrm{~min}$. We compared the formulas of five materials occurred in our result with previous studies on N-containing aromatic compounds for further qualitative and quantitative research. The five standard curves (4-nitrophenol, 4niteocatechol, 3-methyl-4-nitrophenol, 2-methyl-4-nitrophenol, 2-nitro-1-naphthol) were established through the external standard methodology with five-point calibration curves. Finally, we chose points of five different concentrations, which distributed uniformly over the range( $1 \mathrm{ppm}-$ $1 \mathrm{ppb}$ ) which was detected effectively and lower than the saturation concentration.

For the HPLC/DAD-Q-Tof-MS calibration, before starting test, the standard low concentration tuned liquid was used for tuning and calibration instruments, tuned liquid used in ion quality is $112.98558,301.9981,601.9789,1033.9881,1333.9689$ and $1633.9497 \mathrm{Da}$, so based on the analysis of external quality in the process of calibration is not needed in this experiment by five different concentration gradient of mixed standard external standard method to establish standard curve, so as to determine the material content in the samples according to the wavelength of $365 \mathrm{~nm}$. The 
outflow peak time of DAD at $365 \mathrm{~nm}$ was corresponding to the peak data of mass spectrometry, so as to analyze the $\mathrm{BrC}$ substance in the sample.

For light absorption measurement, one filter punch ( $47 \mathrm{~mm}$ diameter) was extracted in $15 \mathrm{~mL}$ methanol ultrasonically for $30 \mathrm{~min}$ and then filtered through a $0.22 \mu \mathrm{m}$ pore size PTFE filter (National Scientific Company). The light absorption of the methanol extracts was measured with a UV/Vis spectrometer (S3100, Scinco) over the wavelength range of 190-700 nm. To convert the light absorption due to chromophores measured in solution to ambient aerosol chromophore concentrations, the light absorption values of all the filter extracts were converted to light absorption coefficients, as shown in equation (1): ${ }^{3}$

$$
A b s_{\lambda}=\left(A_{\lambda}-A_{\lambda}\right) * \frac{V_{l}}{V_{a} * L} \ln (10)
$$

where $A_{700}$ is referenced to account for systematic baseline drift, $\mathrm{V}_{1}\left(\mathrm{~m}^{3}\right)$ is the volume of methanol (30 mL) used for extraction, $\mathrm{V}_{\mathrm{a}}\left(\mathrm{m}^{3}\right)$ is the volume of the sampled air, and $\mathrm{L}(\mathrm{m})$ is the optical path length of the quartz cuvette $(1 \mathrm{~cm})$ in the UV/Vis spectrometer. For ease of analysis, this work focused on $\mathrm{Abs}_{\lambda}$ at $\lambda=365 \mathrm{~nm}$ and $450 \mathrm{~nm}$, where most of the $\mathrm{BrC}$ absorption and cavity attenuated phase shift (CAPS) online monitoring was observed.

\subsection{S Real-time Monitoring of Aerosol Enhanced Light Absorption}

CAPS relies on measuring the average time spent by the light within the sample cell with an optical path length of $1-2 \mathrm{~km}$ and data processed with a time resolution of $1 \mathrm{~s}$. Uncertainties in the extinction and scattering coefficients measured were estimated to be $3 \%{ }^{4}$ A TD system was connected to CAPS to examine the volatilities of the ambient particles. The CAPS was switched between sampling unheated and heated $\left(250^{\circ} \mathrm{C}\right)$ ambient particles every $10 \mathrm{~min}$. With a flow rate of $0.6 \mathrm{~L} / \mathrm{min}$, the residence time of aerosols in the TD heating section was approximately $9 \mathrm{~s}$. The instrument was operated at a volumetric flow rate of $30 \mathrm{~L} / \mathrm{min}$ and the data were acquired every $1 \mathrm{~s}$. Uncertainty in the scattering coefficients measured with the nephelometer was estimated to be $5 \%{ }^{5}$ CAPS and the nephelometer were calibrated before the optical properties of the aerosol were measured in real time. This CAPS was calibrated using 200-nm-diameter polystyrene latex spheres. This instrument provides a calibration-free measure of extinction (manufacturer-estimated accuracy: $5 \%$ ). The extinction measurement occurs in an optical cell which incorporates an integrating-sphere nephelometer. And this nephelometer was calibrated using the extinction measurement by $200-\mathrm{nm}-$ diameter polystyrene latex spheres. The instrument was also calibrated with free-particle air and high-purity $\mathrm{CO} 2$ prior to and after the campaign. Uncertainty in bscat measured with the nephelometer is estimated to be $5 \%$. Measured values were corrected for the angular truncation error in the nephelometer measurements at angles smaller than $7 \circ$ and greater than $170^{\circ}$.

Aerosol absorption enhancement, $E_{a b s}$ is defined as the ratio of the absorption coefficient ( $b_{\text {abs- } \lambda \text { - }}$ unheated $)$ of ambient aerosols at a specific wavelength and the absorption coefficient $\left(b_{\text {abs- } \lambda \text {-heated }}\right)$ at the same wavelength after the aerosols have been heated in a thermal denuder to remove volatilities, as shown in equation (2):

$$
E_{a b s}=\frac{b_{a b s}-\lambda-\text { unheated }}{b_{a b s}-\lambda-\text { heated }}
$$


Absorption ångström exponents (AAE) and scattering ångström exponents (SAE) were used to assess the wavelength dependence of aerosol absorption and scattering coefficients, respectively. For ambient aerosols and uncoated $\mathrm{BC}, \operatorname{AAE}\left(\frac{450}{530}\right)$ and $\operatorname{SAE}\left(\frac{450}{700}\right)$ between 450 and $530 \mathrm{~nm}$, and between 450 and $700 \mathrm{~nm}$, were calculated as shown in equations (3) and (4), respectively:

$$
\begin{gathered}
\operatorname{AAE}\left(\frac{450}{530}\right)=-\frac{\left.\ln \left(b_{a b s}-450-\text { unheated(heated }\right) / b_{a b s}-530-\text { unheated(heated }\right)}{\ln (450 / 530)} \\
\operatorname{SAE}\left(\frac{450}{700}\right)=-\frac{\ln \left(b_{s c a-450} / b_{s c a-700}\right)}{\ln (450 / 700)}
\end{gathered}
$$

\subsection{S Methodologies to Differentiate the Contribution of $\mathrm{BrC}$ and the Lensing Effect to Enhanced Aerosol Light Absorption}

Methodology 1 assumes that the thermal denuder removes all organics effectively. $E_{a b s}$ for the lensing effect is constant at all wavelengths. ${ }^{6-9}$ The aerosol light absorption due to $\mathrm{BrC}$ is calculated as shown in equation (5):

$$
\begin{array}{r}
b_{a b s-450-B r C}=b_{a b s}-450-\text { unheated } \\
-\frac{b_{a b s-530-\text { unheated }}}{b_{a b s-530-\text { heated }}} * b_{a b s-450-\text { heated }} \\
b_{a b s-450-B r C}=b_{a b s-450-\text { unheated }}-E_{a b s}-530 * b_{a b s-450-\text { heated }}
\end{array}
$$

We assume that the absorption of the denuded channel at $\lambda=450 \mathrm{~nm}$ is due entirely to BC. The remainder, being subtracted $E_{\text {abs-530 }}$ caused by the lensing effect, is assumed to be caused by $\mathrm{BrC}$, where $b_{\text {abs-450-BrC }}$ is absorption due to $\mathrm{BrC}$ at $\lambda=450 \mathrm{~nm}, b_{\text {abs-450-unheated }}$ is non-denuded absorption measured at $\lambda=450 \mathrm{~nm}, b_{\text {abs-450-heated }}$ is denuded absorption measured at $\lambda=450 \mathrm{~nm}$, and $E_{\text {abs-530 }}$ is absorption enhancement at $\lambda=530 \mathrm{~nm}$. Due to incomplete removal of low-volatile organics, the estimated fraction of absorption due to $\mathrm{BrC}$ according to methodology 1 is likely to be underestimated.

Methodology 2 assumes that denuded absorption at $\lambda=530 \mathrm{~nm}$ is $\mathrm{BC}$ absorption, the AAE of uncoated $\mathrm{BC}$ is 1, and $E_{\text {abs }}$ for the lensing effect is constant at all wavelengths. ${ }^{9-12}$ Absorption due to $\mathrm{BrC}$ is calculated as shown in equation (6):

$$
\begin{gathered}
b_{a b s-450-B r C}=b_{a b s-450-\text { unheated }}-E_{a b s-530} * b_{a b s-530-\text { heated }} *\left(\frac{530}{450}\right)^{1} \\
b_{a b s-450-B r C}=b_{a b s-450-\text { unheated }}-b_{a b s-530-\text { unheated }} *\left(\frac{530}{450}\right)^{1}
\end{gathered}
$$

Methodology 2 is more accurate than methodology 1 under the circumstance that the thermal denuder cannot effectively remove all of the $\mathrm{BrC}$ absorption at $\lambda=450 \mathrm{~nm}$. $E_{a b s-530}$ at $\lambda=530 \mathrm{~nm}$ is considered to be due to lensing of the $\mathrm{BC}$ core and the same lensing effect is applied on all wavelengths. 
Methodology 3 assumes that denuded absorption at $\lambda=530 \mathrm{~nm}$ represents $\mathrm{BC}$ absorption, $\lambda=530 \mathrm{~nm}$ unheated is caused by $\mathrm{BC}$ absorption and the aerosol lensing effect, and the AAE of coated $\mathrm{BC}$ is 1.6. ${ }^{9-12}$ It has been shown theoretically that the AAE of BC coated with non-absorptive material can be as large as 1.6. ${ }^{9,13}$ We used an AAE of 1 for BC and an AAE of 1.6 for coated BC. The absorption due to $\mathrm{BrC}$ is estimated using equation (7):

$$
b_{a b s-450-B r C}=b_{a b s-450-\text { unheated }}-b_{a b s-530-\text { unheated }} *\left(\frac{530}{450}\right)^{1.6}
$$

where $b_{\text {abs-450-BrC }}$ is absorption due to $\mathrm{BrC}$ at $\lambda=450 \mathrm{~nm}$, and $b_{\text {abs-530-unheated }}$ is non-denuded absorption measured at $\lambda=530 \mathrm{~nm}$.

\section{REFERENCES}

1. Andreae, M. O., Soot carbon and excess fine potassium- long range transport of combustionderived aerosols. Science 1983, 220, (4602), 1148-1151.

2. Wang, Y.; Hu, M.; Lin, P.; Guo, Q.; Wu, Z.; Li, M.; Zeng, L.; Song, Y.; Zeng, L.; Wu, Y.; Guo, S.; Huang, X.; He, L., Molecular characterization of nitrogen-containing organic compounds in humic-like substances emitted from straw residue burning. Environmental Science \& Technology 2017, 51, (11), 5951-5961.

3. Huang, R.-J.; Yang, L.; Cao, J.; Chen, Y.; Chen, Q.; Li, Y.; Duan, J.; Zhu, C.; Dai, W.; Wang, K.; Lin, C.; Ni, H.; Corbin, J. C.; Wu, Y.; Zhang, R.; Tie, X.; Hoffmann, T.; O'Dowd, C.; Dusek, U., Brown carbon aerosol in urban Xi'an, northwest China: The composition and light absorption properties. Environmental Science \& Technology 2018, 52, (12), 6825-6833.

4. Massoli, P.; Kebabian, P. L.; Onasch, T. B.; Hills, F. B.; Freedman, A., Aerosol light extinction measurements by Cavity Attenuated Phase Shift (CAPS) spectroscopy: Laboratory validation and field deployment of a compact aerosol particle extinction monitor. Aerosol Science and Technology 2010, 44, (6), 428-435.

5. Mueller, T.; Laborde, M.; Kassell, G.; Wiedensohler, A., Design and performance of a threewavelength LED-based total scatter and backscatter integrating nephelometer. Atmospheric Measurement Techniques 2011, 4, (6), 1291-1303.

6. Guo, X.; Nakayama, T.; Yamada, H.; Inomata, S.; Tonokura, K.; Matsumi, Y., Measurement of the light absorbing properties of diesel exhaust particles using a three-wavelength photoacoustic spectrometer. Atmospheric Environment 2014, 94, 428-437.

7. Nakayama, T.; Ikeda, Y.; Sawada, Y.; Setoguchi, Y.; Ogawa, S.; Kawana, K.; Mochida, M.; Ikemori, F.; Matsumoto, K.; Matsumi, Y., Properties of light-absorbing aerosols in the Nagoya urban area, Japan, in August 2011 and January 2012: Contributions of brown carbon and lensing effect. Journal of Geophysical Research-Atmospheres 2014, 119, (22), 12721-12739.

8. Cappa, C. D.; Onasch, T. B.; Massoli, P.; Worsnop, D. R.; Bates, T. S.; Cross, E. S.; Davidovits, P.; Hakala, J.; Hayden, K. L.; Jobson, B. T.; Kolesar, K. R.; Lack, D. A.; Lerner, B. M.; Li, S.-M.; Mellon, D.; Nuaaman, I.; Olfert, J. S.; Petaja, T.; Quinn, P. K.; Song, C.; Subramanian, R.; Williams, E. J.; Zaveri, R. A., Radiative Absorption Enhancements Due to the Mixing State of Atmospheric Black Carbon. Science 2012, 337, (6098), 1078-1081.

9. Lack, D. A.; Cappa, C. D., Impact of brown and clear carbon on light absorption enhancement, single scatter albedo and absorption wavelength dependence of black carbon. Atmospheric Chemistry and Physics 2010, 10, (9), 4207-4220. 
10. Cazorla, A.; Bahadur, R.; Suski, K. J.; Cahill, J. F.; Chand, D.; Schmid, B.; Ramanathan, V.; Prather, K. A., Relating aerosol absorption due to soot, organic carbon, and dust to emission sources determined from in-situ chemical measurements. Atmospheric Chemistry and Physics 2013, 13, (18), 9337-9350.

11. Yuan, J. F.; Huang, X. F.; Cao, L. M.; Cui, J.; Zhu, Q.; Huang, C. N.; Lan, Z. J.; He, L. Y., Light absorption of brown carbon aerosol in the PRD region of China. Atmospheric Chemistry and Physics 2016, 16, (3), 1433-1443.

12. Bahadur, R.; Praveen, P. S.; Xu, Y.; Ramanathan, V., Solar absorption by elemental and brown carbon determined from spectral observations. Proceedings of the National Academy of Sciences of the United States of America 2012, 109, (43), 17366-17371.

13. Gyawali, M.; Arnott, W. P.; Lewis, K.; Moosmueller, H., In situ aerosol optics in Reno, NV, USA during and after the summer 2008 California wildfires and the influence of absorbing and nonabsorbing organic coatings on spectral light absorption. Atmospheric Chemistry and Physics 2009, 9, (20), 8007-8015. 